\title{
Insulinoma-Associated Protein 2
}

National Cancer Institute

\section{Source}

National Cancer Institute. Insulinoma-Associated Protein 2. NCI Thesaurus. Code C148305.

Insulinoma-associated protein $2(566 \mathrm{aa}, \sim 59 \mathrm{kDa}$ ) is encoded by the human INSM2 gene. This protein plays a role in cell growth regulation and tumor suppression. 